\begin{tabular}{|c|c|c|c|}
\hline Case Reports $i$ & \multicolumn{2}{|c|}{ Case Rep Gastroenterol 2015;9:188-193 } & \multirow{3}{*}{$\begin{array}{l}\text { Karger } \\
\text { Open access }\end{array}$} \\
\hline Gastroenterology & $\begin{array}{l}\text { DOI: } 10.1159 / 000430946 \\
\text { Publisnea onine: June } 3,2015\end{array}$ & $\begin{array}{l}\text { ( ) } 2015 \text { S. Karger AG, Basel } \\
1662-0631 / 15 / 0092-0188 \$ 39.50 / 0 \\
\text { www.karger.com/crg }\end{array}$ & \\
\hline & \multicolumn{2}{|c|}{$\begin{array}{l}\text { This is an Open Access article licensed under the terms of the Creative Commons } \\
\text { Attribution-NonCommercial } 3.0 \text { Unported license (CC BY-NC) (www.karger.com/OA } \\
\text { license), applicable to the online version of the article only. Distribution permitted for non } \\
\text { commercial purposes only. }\end{array}$} & \\
\hline
\end{tabular}

\title{
A Case of Intestinal Mastocytosis Misdiagnosed as Crohn's Disease
}

\author{
Stefania Reggiani ${ }^{a} \quad$ Loretta Cosso $^{a} \quad$ Alessandro Adriani ${ }^{a}$ \\ Stefano Pantaleoni ${ }^{a} \quad$ Alessandro Risso $^{a} \quad$ Federico Vittone $^{b}$ \\ Luigi Chiusa $^{b}$ Nicoletta Sapone ${ }^{a} \quad$ Marco Astegiano $^{a}$ \\ Division of ${ }^{\mathrm{a}}$ Gastroenterology and ${ }^{\mathrm{b}}$ Anatomical Pathology, AOU Città della Salute e della \\ Scienza di Torino, University of Turin, Turin, Italy
}

\section{Key Words}

Systemic mastocytosis · Gastrointestinal symptoms · Differential diagnosis · Crohn's disease

\begin{abstract}
Systemic mastocytosis (SM) is a rare, heterogeneous and progressive disease, characterized by the accumulation of atypical mast cells in various organs, including the gastrointestinal tract. Gastrointestinal symptoms are present in up to $80 \%$ of patients with SM, the most common being abdominal pain, diarrhea, nausea and vomiting. Up to $50 \%$ of patients with SM do not have classical skin lesions at presentation, and in these patients the diagnosis of SM can be difficult for years. Here we report a case of SM that initially mimicked inflammatory bowel disease, although the patient showed poor response to steroid therapy. The right diagnosis was made only on the surgical specimen obtained after emergency surgery for intestinal obstruction. SM should therefore be considered in the diagnostic approach in patients with gastrointestinal symptoms not attributable to other pathologies and in cases of suspected inflammatory bowel disease with unusual course.

(c) 2015 S. Karger AG, Basel
\end{abstract}

\section{Introduction}

Mastocytosis is a rare and heterogeneous disease characterized by the accumulation of abnormal mast cells in various tissues. While cutaneous mastocytosis (skin-localized form) is the classical presentation in children and in pediatric cases tends to resolve spontaneously at puberty [1], systemic mastocytosis (SM) is more frequent in adults, is characterized by mast cells infiltration of extracutaneous organs (e.g. bone marrow, liver, spleen, gastrointes- 
Reggiani et al.: A Case of Intestinal Mastocytosis Misdiagnosed as Crohn's Disease

tinal tract, lymph nodes); this form is progressive and has no tendency to regress. Both forms of mastocytosis might be considered myeloproliferative disorders [1].

In most patients, SM is caused by mutations in the KIT oncogene (in particular the D816V mutation is present in $>80 \%$ of patients), which are responsible for c-kit receptor autophosphorylation, inducing differentiation, migration, accumulation of mast cells and their activation in tissues [2]; therefore, this receptor is now considered a therapeutic target using tyrosine kinase inhibitors.

The clinical manifestations of SM are related to the release of mast cells mediators (e.g. facial flushing, urticaria, itching, diarrhea) or to uncontrolled growth and infiltration of clonal mast cells in different organs (e.g. hepatomegaly, liver fibrosis and rarely cirrhosis, splenomegaly, osteoporosis, malabsorption, pancreatic insufficiency); most of the symptoms, though not being life-threatening, may induce a significant impairment of quality of life [3]. Nevertheless, when infiltration results in organ function impairment, the disease is considered aggressive and may decrease life expectancy [4, 5].

Up to $50 \%$ of patients with SM do not show classical skin lesions at presentation, and in these patients the diagnosis of SM can be difficult for years [6]: according to the World Health Organization (WHO) diagnostic criteria, SM is diagnosed when the major and at least one minor criterion or three minor criteria are satisfied (table 1) [7]. Its signs and symptoms are divided into two groups: B symptoms ('borderline benign - be watchful') and C symptoms ('consider cytoreductive therapy') (table 2) [7].

Gastrointestinal symptoms are reported in up to $80 \%$ of patients with SM, are often chronic and represent a major source of morbidity [8]: abdominal pain is the most common, while diarrhea is present in about $40 \%$ of patients with gastrointestinal symptoms and nausea and vomiting occur in approximately $30 \%$. A prevalence of $10 \%$ is estimated for gastrointestinal bleeding, in about $25 \%$ of cases caused by peptic ulcer disease [9].

At present there is no curative therapy for SM and the medical approach is aimed at symptomatic relief and improvement in terms of quality of life: SM patients should avoid mast cell degranulation triggers (e.g. exposure to heat, cold, acute emotional stress, very strenuous exercise, alcohol), and commonly used symptomatic drugs are $\mathrm{H}_{1}$ and $\mathrm{H}_{2}$ histamine receptor blockers, ketotifen, cromolyn sodium and anti-leukotriene drugs, while cytoreductive regimens are indicated in SM with C symptoms [10,11].

\section{Case Report}

A 47-year-old woman, with a past medical history including Turner's syndrome with primary amenorrhea, polycystic kidney disease and previous appendectomy for acute appendicitis, was admitted to our hospital in 1995 for worsening fatigue, iron deficiency anemia and weight loss (BMI of 16 at time of admission).

According to endoscopic (upper and lower gastrointestinal endoscopies), biochemical (neutrophilic leukocytosis and elevation of phlogosis markers) and radiologic (abdominal ultrasonography scan, small bowel enema, barium enema) findings, she was discharged with a diagnosis of Crohn's disease involving the terminal ileum. Oral treatment with tapering corticosteroid (prednisone, starting with $50 \mathrm{mg} /$ day and reducing by $5 \mathrm{mg}$ every week) was then started, but with poor clinical improvement.

Two months after the end of steroid tapering, the patient underwent emergency right colectomy, resection of the terminal ileum $(70 \mathrm{~cm})$ and ileocolic anastomosis for acute abdomen due to bowel obstruction. The following scenario presented to the surgeons: relaxed and edematous preterminal ileum, stenotic and anelastic terminal ileum and wiry colon. 
Reggiani et al.: A Case of Intestinal Mastocytosis Misdiagnosed as Crohn's Disease

Macroscopic pathological analysis revealed an ileal wall with regular thickness, expanded lumen and hyperemic mucosa and, 30 and $50 \mathrm{~cm}$ before the ileocecal valve, two salient features $1 \mathrm{~cm}$ in diameter covered with regular mucosa; when cut, they appeared as whitish nodes located in the submucosa.

Microscopic pathological examination showed substantial preservation of the architecture of the ileal wall and presence in the lamina propria of lymphocytes, plasma cells, eosinophils and a great number of partially degranulated mast cells (20/30 high-power fields), identified by immunohistochemical stains for tryptase. Many mast cells were found even in the mucosa, submucosa and tunica serosa (fig. 1), and the above-mentioned ileal whitish nodes resulted fibrotic and populated by fibroblasts, mast cells, plasma cells and lymphocytes. Giemsa and Masson trichrome stainings, immunohistochemistry for actin, desmin, S100 protein, CD3, CD20 and neurofilaments were performed; according to histology, a diagnosis of intestinal involvement by SM was performed.

During the following years the patient underwent regular follow-up; she always remained asymptomatic for cutaneous or systemic symptoms and only occasional episodes of diarrhea were reported. In 2004 she underwent kidney transplantation for polycystic kidney disease and over the years she developed portal hypertension with esophageal varices in a context of Caroli disease. At the last medical outpatient visit (November 2010) the patient was in good condition and without any systemic symptoms; she was just suffering from sporadic flares of diarrhea.

Because of the peculiarity of the present case, a biopsy of the surgical specimen was recovered to perform immunohistochemistry analysis for CD117/c-kit (fig. 2) and CD25, obtaining the ultimate confirmation that she was fulfilling the WHO diagnostic criteria for SM.

\section{Discussion}

Gastrointestinal symptoms (e.g. abdominal pain, diarrhea, nausea and vomiting, subocclusion) are present in up to $80 \%$ of patients affected by SM and contribute to the morbidity of this disease. Symptoms are caused by the release of mast cell mediators or by tissue infiltration of clonal mast cells. According to the WHO criteria, diagnosis is based on histological finding of atypical mast cells in tissue section, associated with mutation of c-kit or coexpression of CD2/CD25 or associated with persistent elevation of serum tryptase levels.

In case of gastrointestinal involvement, pathological findings could be detected at endoscopic and radiologic examinations. The features of small bowel SM involvement can include thickened folds, nodular mucosa, edematous or scalloped folds and dilated bowel loops; these findings are also typical for inflammatory bowel disease. Histological documentation in the small bowel can show, apart from the presence of a high number of atypical mast cells, increased plasma cell and eosinophil content in the lamina propria; villous fluttering and atrophy can be present.

In our patient, clinical presentation was atypical both for inflammatory bowel disease and SM; the relatively advanced age of onset and non-response to steroid therapy could question the diagnosis of inflammatory disease. The occurrence of acute abdomen with the need for emergency surgery allowed us, however, a deep and complete histological study of the surgical specimen and eventually led us to the diagnosis. SM should always be considered in the differential diagnosis of bowel obstruction in adulthood, with or without significant previous cutaneous or gastrointestinal symptoms and even when a previous diagnosis of gastrointestinal disease other than SM has been made, especially if this is not entirely convincing. 
Reggiani et al.: A Case of Intestinal Mastocytosis Misdiagnosed as Crohn's Disease

\section{Statement of Ethics}

We obtained the patient's written informed consent to publish this case report and the publication has been approved by our institute's committee on human research.

\section{Disclosure Statement}

We disclose no sponsorship or funding arrangements relating to this research and no possible conflicts of interest.

\section{References}

1 Bodemer C, Hermine O, Palmérini F, Yang Y, Grandpeix-Guyodo C, Leventhal PS, Hadj-Rabia S, Nasca L, Georgin-Lavialle S, Cohen-Akenine A, Launay JM, Barete S, Feger F, Arock M, Catteau B, Sans B, Stalder JF, Skowron F, Thomas L, Lorette G, Plantin P, Bordigoni P, Lortholary O, de Prost Y, Moussy A, Sobol H, Dubreuil P: Pediatric mastocytosis is a clonal disease associated with D816V and other activating c-KIT mutations. J Invest Dermatol 2010;130:804-815.

2 Valent P, Akin C, Escribano L, Födinger M, Hartmann K, Brockow K, Castells M, Sperr WR, Kluin-Nelemans HC, Hamdy NA, Lortholary O, Robyn J, van Doormaal J, Sotlar K, Hauswirth AW, Arock M, Hermine O, Hellmann A, Triggiani M, Niedoszytko M, Schwartz LB, Orfao A, Horny HP, Metcalfe DD: Standard and standardization in mastocytosis: consensus statements on diagnostics, treatment, recommendations and response criteria. Eur J Clin Invest 2007;37:435-453.

- 3 Hermine 0, Lortholary 0, Leventhal PS, Catteau A, Soppelsa F, Baude C, Cohen-Akenine A, Palmérini F, Hanssens K, Yang Y, Sobol H, Fraytag S, Ghez D, Suarez F, Barete S, Casassus P, Sans B, Arock M, Kinet JP, Dubreuil P, Moussy A: Case-control cohort study of patients' perceptions of disability in mastocytosis. PLoS One 2008;3:e2266.

4 Lim KH, Tefferi A, Lasho TL, Finke C, Patnaik M, Butterfield JH, McClure RF, Li CY, Pardanani A: Systemic mastocytosis in 342 consecutive adults: survival studies and prognostic factors. Blood 2009;113:57275736.

5 Pardanani A, Lim KH, Lasho TL, Finke C, McClure RF, Li CY, Tefferi A: Prognostically relevant breakdown of 123 patients with systemic mastocytosis associated with other myeloid malignancies. Blood 2009;114: 3769-3772.

6 Jensen RT: Gastrointestinal abnormalities and involvement in systemic mastocytosis. Hematol Oncol Clin North Am 2000;14:579-623.

7 Valent P, Akin C, Sperr WR, Horny HP, Arock M, Lechner K, Bennett JM, Metcalfe DD: Diagnosis and treatment of systemic mastocytosis: state of the art. Br J Haematol 2003;122:695-717.

$\checkmark 8$ Cherner JA, Jensen RT, Dubois A, O’Dorisio TM, Gardner JD, Metcalfe DD: Gastrointestinal dysfunction in systemic mastocytosis. A prospective study. Gastroenterology 1988;95:657-667.

-9 Sokol H, Georgin-Lavialle S, Grandpeix-Guyodo C, Canioni D, Barete S, Dubreuil P, Lortholary O, Beaugerie L, Hermine 0: Gastrointestinal involvement and manifestations in systemic mastocytosis. Inflamm Bowel Dis 2010;16:1247-1253.

$\$ 10$ Pardanani A, Akin C, Valent P: Pathogenesis, clinical features, and treatment advances in mastocytosis. Best Pract Res Clin Haematol 2006;19:595-615.

11 Kluin-Nelemans HC, Oldhoff JM, van Doormaal JJ, van 't Wout JW, Verhoef G, Gerrits WB, van Dobbenburgh OA, Pasmans SG, Fijnheer R: Cladribine therapy for systemic mastocytosis. Blood 2003;102:4270-4276. 
Reggiani et al.: A Case of Intestinal Mastocytosis Misdiagnosed as Crohn's Disease

Table 1. WHO diagnostic criteria for SM (modified from [7])

Major criterion

- Multifocal dense infiltrates of mast cells (>15 mast cells in aggregates) at bone marrow biopsy and/or in sections of other extracutaneous organ(s)

Minor criteria

- $\quad>25 \%$ of mast cells in bone marrow are atypical cells or spindle-shaped mast cells in infiltrates detected on sections of extracutaneous organ(s)

- c-kit point mutation at codon 816 in the bone marrow or in another extracutaneous organ(s)

- Mast cells in the bone marrow or in another extracutaneous organ(s) expressing CD2 and/or CD25

- Serum tryptase levels $>200 \mathrm{ng} / \mathrm{ml}$ (this criterion is valid only if associated hematopoietic clonal nonmast cell lineage disease SM has been excluded)

Table 2. SM findings related to mast cell infiltration and proliferation (modified from [7])

\begin{tabular}{ll}
\hline B symptoms (borderline benign - be watchful) & C symptoms (consider cytoreductive therapy) \\
\hline Hepatomegaly & Anemia $(\mathrm{Hb}<10 \mathrm{~g} / \mathrm{dl})$ \\
Splenomegaly & Thrombocytopenia $\left(<100,000 / \mathrm{mm}^{3}\right)$ \\
Lymphadenopathy & Neutropenia \\
Hypercellular bone marrow & Ascites or portal hypertension \\
Mast cell infiltration in bone marrow $>30 \%$ & Hypersplenism \\
Serum tryptase level $>200 \mathrm{ng} / \mathrm{ml}$ & Malabsorption with weight loss \\
& Osteolysis with pathological bone fractures \\
\hline
\end{tabular}



Fig. 1. Hematoxylin and eosin stain of random sampling in the colon with chronic inflammation and a conspicuous number of intramucosal mast cells. 


\begin{tabular}{rl|l} 
Case Reports in & \multicolumn{2}{l}{} \\
\cline { 2 - 3 } Gastroenterology & Case Rastroenterol 2015;9:188-193 & $\begin{array}{l}\text { ( 2015 S. Karger AG, Basel } \\
\text { www.karger.com/crg }\end{array}$ \\
\cline { 2 - 3 } & DOI: 10.1159/000430946 &
\end{tabular}

Reggiani et al.: A Case of Intestinal Mastocytosis Misdiagnosed as Crohn's Disease

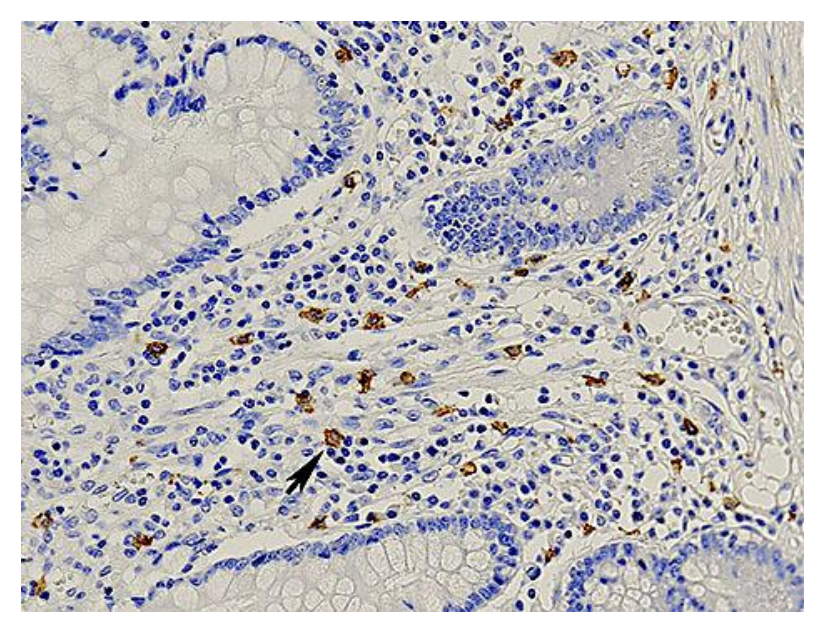

Fig. 2. Immunoperoxidase stain for CD117. The stain reveals mast cells with strong membrane and cytoplasmic reaction (an example is highlighted by the arrow). In particular, more than 20 mast cells per highpower field are visible in the figure, in accordance with the major diagnostic WHO criteria. 